\title{
New records of lichen-forming fungi from Fiji
}

\author{
H. Thorsten Lumbsch', Robert Lücking1', Pradeep Divakar², Matt von \\ Konrat ${ }^{1}$ and Alifereti Naikatini ${ }^{3}$
}
${ }^{1}$ Department of Botany, The Field Museum, 1400 S. Lake Shore Drive, Chicago, IL 60605, USA
${ }^{2}$ Departamento de Biología Vegetal II, Facultad de Farmacia, Universidad Complutense de Madrid, Plaza de Ramón y Cajal s/n, 28040 Madrid, Spain
${ }^{3}$ Institute of Applied Science, Faculty of Science and Technology, University of the South Pacific,
Private Bag, Laucala Campus, Suva, Fiji

\begin{abstract}
Sixty-six species are recorded for the first time from the Fijian archipelago. Diagnostic features and distribution areas are given for each species reported here. The genera Bactrospora, Badimia, Baeomyces, Calenia, Coccotrema, Dibaeis, Gyalectidium, Gyalideopsis, Lecanora, Lepraria, Leucodecton, Megalospora, Melanotopelia, Pannaria, Peltigera, Pyxine, Strigula, Thalloloma, and Thelotrema are reported here from Fiji for the first time. The majority of new records belong to pan- or palaeo-tropical species, in addition to cosmopolitan, Australasian and Indo-Pacific elements.
\end{abstract}

\section{Introduction}

The Fijian archipelago is located in the tropical south-west Pacific, between $15^{\circ}$ and $22^{\circ} \mathrm{S}$ and $177^{\circ} \mathrm{W}$ and $175^{\circ} \mathrm{E}$. It is made up of more than 300 oceanic islands, covering a total land area of $18,376 \mathrm{~km}^{2}$. Fiji's tropical maritime climate is influenced by the south-east trade winds and together with rugged topography and mountain ranges in the main islands that rise up to $1300 \mathrm{~m}$ provide suitable habitats for lichens both on the leeward and windward sides. These habitats include cloud forests, upland tropical rainforest, lowland tropical rainforest, dry forests, mangrove forests and coastal forests to name a few. Heads (2006) gives a summary of the recent floristic accounts in Fiji where all the major groups have been covered, an uncommon phenomenon in the wet tropical countries of the world. However, only the pteridophytes and seed plants have been treated in any detail and this is not so for the lower plants and fungi. Also there have only been a few vegetation and ecological studies in Fiji in the past (Keppel 2005).

The lichen flora of Fiji is currently poorly known. Krempelhuber (1873) listed several lichens in a paper on lichens from the South Pacific and later Zahlbrucker (1896) recorded additional species from the archipelago. Only a few recent 
studies have specifically focused on Fijian lichens (Archer 2004, Elix 2001, Lücking et al. 2010, Lumbsch et al. 2009, McCarthy \& Elix 2000, Molho et al. 1981). A recently updated checklist of Fijian lichens includes 159 species (Elix \& McCarthy 1998, 2008).

On a joint expedition to Fiji in 2008 organised by Matt von Konrat (The Field Museum, Chicago), the first author collected lichens in the highlands of Taveuni and Viti Levu (Fiji). A map showing the locations of the localities is found in von Konrat et al. (2011, this issue). The following list includes 66 new records for the Fijian archipelago, which brings the number of lichen species known from Fiji to 225. This contribution adds 19 further genera to the lichen flora of Fiji.

\section{New records}

Amandinea melaxanthella (Nyl.) Marbach, Bibl. Lichenol. 74: 87 (2000)

Illustration: Fig. 1A.

Distribution: pantropical (Marbach 2000).

Notes: this species is characterised by multi-spored asci, small ascospores, and the presence of the arthothelin chemosyndrome (Marbach 2000).

Specimens examined: Fiji: Taveuni: Coconut Research Station, altitude $24 \mathrm{~m}$, on Cocos nucifera, Lumbsch 19809c (F, SUVA).

Anisomeridium ubianum (Vain.) R.C.Harris, More Florida Lichens: 151 (1995)

Illustration: Fig. 1B.

Distribution: Indo-Pacific (Harada 2001, Harris 1995).

Notes: this corticolous species is characterised by dark, hemispherical to dome-shaped ascomata, lateral to subapical ostioles, and relatively large ascospores (Harada 2001).

Specimens examined: Fiji: Viti Levu: Nadi area, close to Navisabasaba village, on road to Naduga from Nadi, mangrove, altitude $2 \mathrm{~m}$, on mangrove, Lumbsch 19845j (F, SUVA).

Bactrospora metabola (Nyl.) Egea \& Torrente, Mycotaxon 53: 58 (1995)

Illustration: Fig. 1C.

Distribution: Indo-Pacific (Egea \& Torrente 1995).

Notes: Bactrospora metabola is characterised by 4-8-spored, pyriform, wide asci and muriform ascospores (Egea \& Torrente 1995).

Specimens examined: Fiji: Viti Levu: Nadi area, close to Navisabasaba village, on road to Naduga from Nadi, mangrove, altitude $2 \mathrm{~m}$, on mangrove, Lumbsch 19845h (F, SUVA).

Badimia elegans (Vain.) Vězda, Folia Geobot. Phytotax. 21: 215 (1986)

Illustration: Fig. 1D.

Distribution: Indo-Pacific (Santesson 1952).

Notes: this Badimia species, which belongs to the nominal section with vividly coloured apothecia with opaque discs and thick margins (Lücking 2008), has orangered apothecia, 3-septate ascospores, and a smooth thallus surface (Santesson 1952).

Specimens examined: Fiji: Viti Levu: Nadarivatu Nature Reserve, secondary forest at 
road to Koro'o, secondary forest dominated by Agathis and Podocarpus, altitude $750 \mathrm{~m}$, on leaves, Lumbsch 19852a (F, SUVA).

Baeomyces heteromorphus Nyl. ex C. Bab. \& Mitt., in Hooker, Flora Tasman. 2: 351 (1860) Illustration: Fig. 1E.

Distribution: this Australasian species has previously been known from mainland Australia, New Guinea, New Zealand, and Tasmania (Galloway 1980, 2007; Johnston 2001, Streimann 1986).

Notes: this variable species is characterised by a greenish-grey corticate thallus, brownish apothecial discs, non-septate, hyaline ascospores, and the presence of the norstictic acid chemosyndrome (Galloway 1980, Johnston 2001).

Specimens examined: Fiji: Viti Levu: Monasavu, road to the Nabilabila intake, off the MonasavuWainisavulevu Fiji Electricity Authority access road, cloud forest, altitude 1200 m, on soil, Lumbsch 19832a, $c ; 19839 c$, $d$ (F, SUVA).

Brigantiaea leucoxantha (Spreng.) R.Sant. \& Hafellner, in Hafellner \& Bellemère, Nova Hedwigia 35: 246 (1982)

Illustration: Fig. 1F.

Distribution: pantropical (Hafellner 1997).

Notes: this is a non-sorediate, corticolous taxon with a hyaline to yellowish hypothecium and orange crystals in the exciple (Hafellner 1997).

Specimens examined: Fiji: Taveuni: Access road to summit of Devo Peak, altitude $700 \mathrm{~m}$, montane relict forest at roadside, on bark, Lumbsch 19804d (F, SUVA).

Byssoloma leucoblepharum (Nyl.) Vain., Dansk Bot. Ark. 4(11): 23 (1926)

Illustration: Fig. 2A.

Distribution: pantropical (Lücking 2008).

Notes: this taxon has a dark greenish grey thallus, a dark grey-brown apothecial disc, well-developed exciple lacking crystals, and 3-septate ascospores (Lücking 2008).

Specimens examined: Fiji: Viti Levu: Monasavu, road to the Nabilabila intake, off the MonasavuWainisavulevu Fiji Electricity Authority access road, altitude 1200 m, cloud forest, on leaves, Lumbsch 19835 a (F, SUVA).

Calenia depressa Müll.Arg., Lich. Epiphylli Novi: 4 (1890)

Illustration: Fig. 2B.

Distribution: pantropical (Lücking 2008).

Notes: this taxon is distinguished from similar Calenia spp. by having dark grey apothecial discs, and usually 7-septate ascospores (Lücking 2008).

Specimens examined: Fiji: Taveuni: Bouma Falls, altitude $10 \mathrm{~m}$, relict forest, on leaves, Lumbsch 19816a (F, SUVA). Viti Levu: Monasavu, road to the Nabilabila intake, off the MonasavuWainisavulevu Fiji Electricity Authority access road, cloud forest, on leaves, Lumbsch $19835 f$ (F, SUVA).

Chrysothrix xanthina (Vain.) Kalb, Bibl. Lichenol. 78: 144 (2001)

Illustration: Fig. 2C.

Distribution: pantropical (Kalb 2001).

Notes: this yellow, leprose species differs from the morphologically similar Chrysothrix 


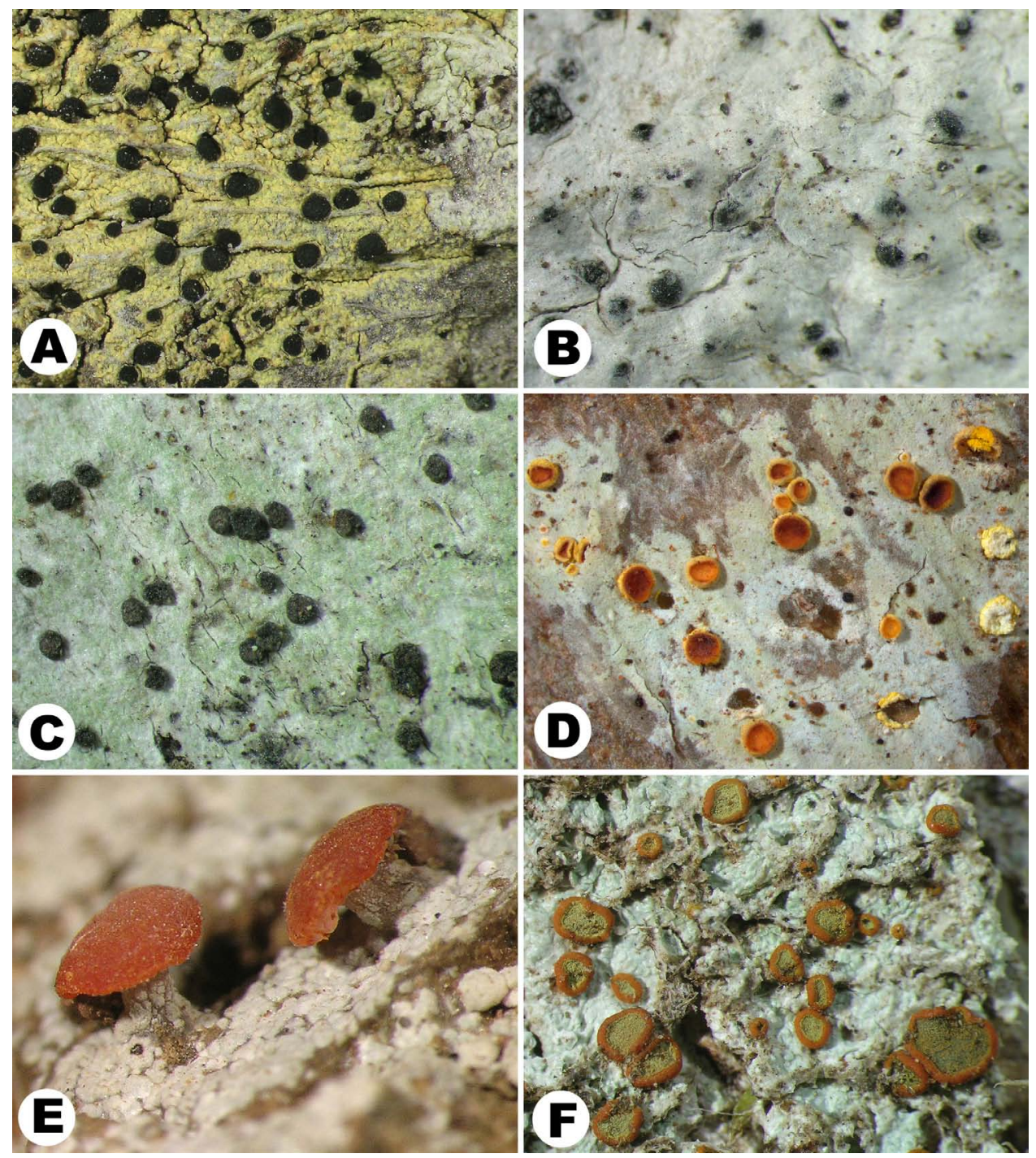

Fig. 1. A, Amandinea melaxanthella. B, Anisomeridium ubianum. C, Bactrospora metabola. D, Badimia elegans. E, Baeomyces heteromorphus. F Brigantiaea leucoxantha. 

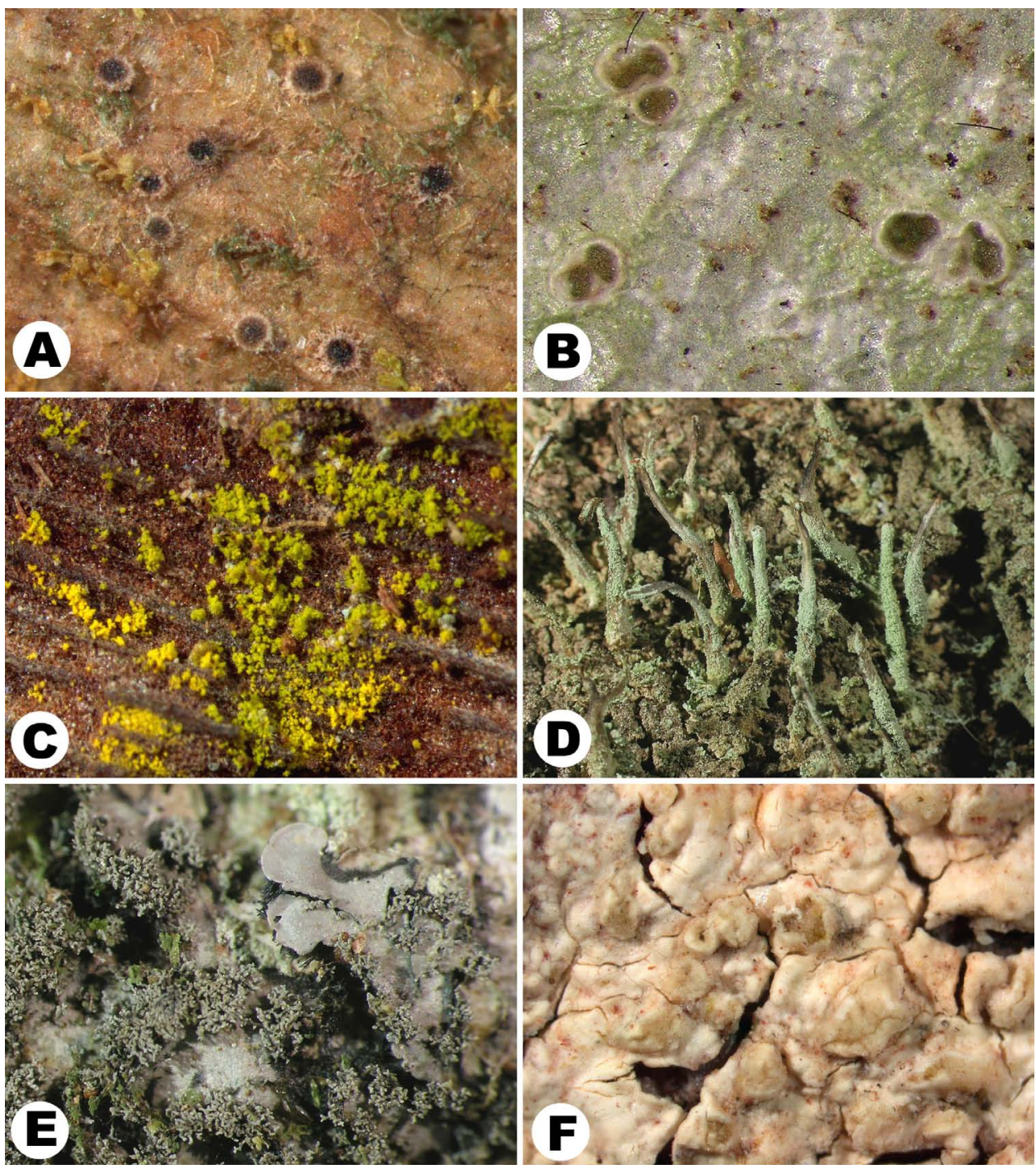

Fig. 2. A, Byssoloma leucoblepharum. B, Calenia depressa. C, Chrysothrix xanthina. D, Cladonia macilenta. E, Coccocarpia glaucina. F, Coccotrema cucurbitula. 
candelaris (L.) J.R.Laundon by containing pinastric acid (rather than calycin) (Kalb 2001).

Specimens examined: Fiji: Taveuni: near Wiwi village, altitude $1 \mathrm{~m}$, degraded mangrove, on Cocos nucifera, Lumbsch 19818a (F, SUVA).

Cladonia macilenta Hoffm., Deutschl. Fl. 2: 126 (1796)

Illustration: Fig. 2D.

Distribution: cosmopolitan.

Notes: this cosmopolitan species is characterised by having simple to rarely branched, escypherous, ecorticate podetia, red apothecia and pycnidia, and the presence of the barbatic acid chemosyndrome (Archer 1992).

Specimens examined: Fiji: Viti Levu: Monasavu, Guesthouse close to the dam, altitude 900m, trees at parking lot of guesthouse, on Cyathea, Lumbsch $19830 b$ (F, SUVA).

Coccocarpia glaucina Kremp., Nuovo Giorn. Bot. Ital. 7: 14 (1875)

Illustration: Fig. 2E.

Distribution: Pacific and north-eastern Australia (Arvidsson 1982, 1992).

Notes: this species has canaliculate lobes with mostly marginal, distinctly flattened, microphylline isidia (Arvidsson 1982, 1992).

Specimens examined: Fiji: Taveuni: access road to summit of Devo Peak, altitude $700 \mathrm{~m}$, montane relict forest at roadside, on bark, Lumbsch 19805c (F, SUVA); Bouma Falls, altitude $10 \mathrm{~m}$, relict forest, on bark, Lumbsch 19815k (F, SUVA).

Coccotrema cucurbitula (Mont.) Müll.Arg., Nuovo Giorn. Bot. Ital. 21: 51 (1889)

Illustration: Fig. 2F.

Distribution: Pacific; widely distributed in southern South America, south-east Australia, Tasmania, New Zealand, and other pacific islands (Messuti 1996).

Notes: this species is readily distinguished by the perithecioid ascomata with periphysoids, large, one-celled, hyaline ascospores, and the presence of the norstictic chemosyndrome (Messuti 1996, Messuti \& Vobis 2002).

Specimens examined: Fiji: Viti Levu: Monasavu, road to the Nabilabila intake, off the MonasavuWainisavulevu Fiji Electricity Authority access road, altitude $950 \mathrm{~m}$, Agathis-Dacrydium dominated upland forest, on bark, Lumbsch 19825e; $19825 f$ (F, SUVA).

Coenogonium congense Dodge, Ann. Miss. Bot. Gard. 40: 350 (1953)

Illustration: Fig. 3A.

Distribution: pantropical (Dodge 1953, Rivas Plata et al. 2006).

Notes: this recently resurrected Coenogonium has a shelf-like, compact thallus with narrow algal filaments and 2-celled, biseriate ascospores (Rivas Plata et al. 2006).

Specimens examined: Fiji: Viti Levu: Nadarivatu Nature Reserve, secondary mountain forest at road to Koro'o, altitude $750 \mathrm{~m}$, secondary mountain forest dominated by Agathis and Podocarpus, on bark, Lumbsch 19849h (F, SUVA).

Coenogonium flavum (Malcolm \& Vězda) Malcolm, Australas. Lichenology 54: 19 (2004)

Illustration: Fig. 3B.

Distribution: pantropical (Rivas Plata et al. 2006). 
Notes: this Coenogonium species has a crustose thallus, lacks isidia, and has tubular, straight pycnidia with conidia up to $2 \mu \mathrm{m}$ broad (Rivas Plata et al. 2006).

Specimens examined: Fiji: Taveuni: near Wiwi village, altitude $1 \mathrm{~m}$, degraded mangrove forest, on mangrove, Lumbsch 19817c (F, SUVA).

Coenogonium nepalense (G.Thor \& Vězda) Lücking, Aptroot \& Sipman, Fungal Diversity 23: 297 (2006)

Illustration: Fig. 3C.

Distribution: pantropical (Rivas Plata et al. 2006).

Notes: Coenogonium nepalense is readily distinguished among the crustose Coenogonium spp. by having short, narrowly ellipsoid ascospores and medium-sized, pale yellow apothecia (Rivas Plata et al. 2006).

Specimens examined: Fiji: Taveuni: near Wiwi village, altitude $1 \mathrm{~m}$, degraded mangrove forest, on mangrove, Lumbsch 19817b (F, SUVA).

Cyphellostereum pusiolum (Berk. \& M.A.Curtis) D.A.Reid, Beih. Nova Hedwigia 18: 342 (1965)

Illustration: Fig. 3D.

Distribution: pantropical (Aptroot \& Sipman 1991).

Notes: this lichenised basidiomycete occurs on soil and mosses.

Specimens examined: Fiji: Viti Levu: Monasavu, road to the Nabilabila intake, off the MonasavuWainisavulevu Fiji Electricity Authority access road, altitude 1200 m, cloud forest, on soil, Lumbsch $19839 b$ (F, SUVA).

Dibaeis absoluta Kalb \& Gierl, in Gierl \& Kalb, Herzogia 9: 613 (1993)

Illustration: Fig. 3E.

Distribution: pantropical (Gierl \& Kalb 1993).

Notes: this species is readily distinguished by the sessile to shortly stalked, pink apothecia, absence of soredia, and the presence of the baeomycesic acid chemosydrome (Gierl \& Kalb 1993).

Specimens examined: Fiji: Viti Levu: Monasavu, road to the Nabilabila intake, off the MonasavuWainisavulevu Fiji Electricity Authority access road, altitude 1200 m, cloud forest, on soil, Lumbsch $19832 b$ (F, SUVA).

Dibaeis sorediata Kalb \& Gierl, in Gierl \& Kalb, Herzogia 9: 615 (1993)

Illustration: Fig. 3F.

Distribution: palaeotropical (Gierl \& Kalb 1993).

Notes: the combination of shortly stalked to sessile apothecia and the presence of soredia characterise this species. D. absoluta is similar but lacks soredia (Gierl \& Kalb 1993).

Specimens examined: Fiji: Viti Levu: Nadarivatu Nature Reserve, roadside on road to Koro'o, altitude $900 \mathrm{~m}$, on soil, Lumbsch 19848b (F, SUVA).

Dictyonema irpicinum (Mont.) Nyl., Ann. Sci. Nat., Bot., sér. 4, 11: 240 (1859)

Illustration: Fig. 4A.

Distribution: pantropical (Chaves et al. 2004). 

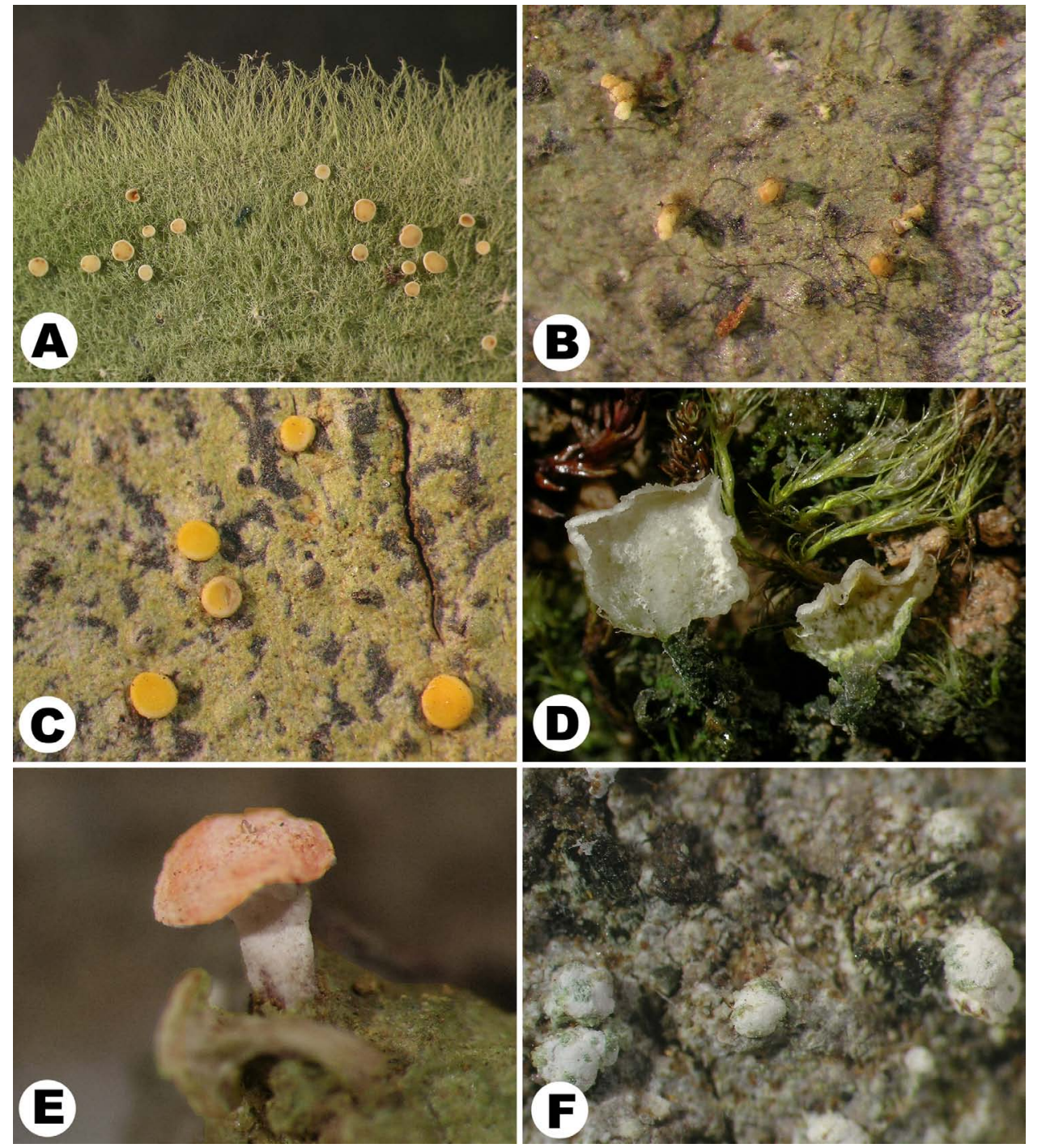

Fig. 3. A, Coenogonium congense. B, Coenogonium flavum. C, Coenogonium nepalense. D, Cyphellostereum pusiolum. E, Dibaeis absoluta. F, Dibaeis sorediata. 

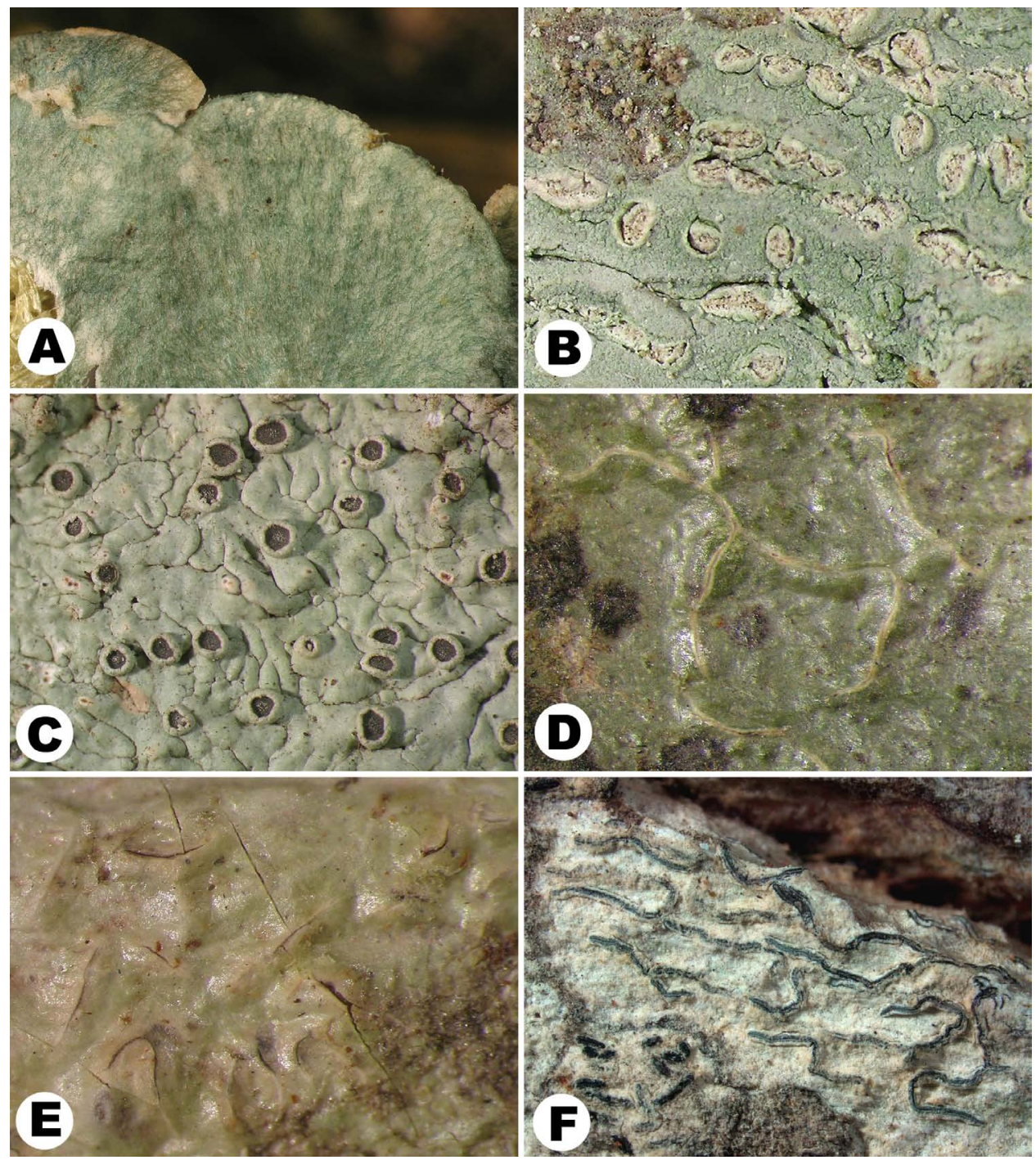

Fig. 4. A, Dictyonema irpicinum. B, Diorygma hieroglyphicum. C, Dirinaria confluens. D, Fissurina dumastii. E, Fissurina dumastioides. F, Graphis caesiella. 
Notes: this species forms semicircular cushions of intricate cyanobacterial filaments surrounded by a fungal hyphal sheath. It resembles $D$. sericeum but differs in the presence of clamps in the free fungal hyphae.

Specimens examined: Fiji: Viti Levu: Monasavu, road to the Nabilabila intake, off the MonasavuWainisavulevu Fiji Electricity Authority access road, altitude 1200 m, cloud forest, on bark, Lumbsch 19837e (F, SUVA).

Diorygma hieroglyphicum (Pers.) Staiger \& Kalb, in Kalb et al., Symb. Bot. Upsal. 34(1): $151(2004)$

Illustration: Fig. 4B.

Distribution: pantropical (Kalb et al. 2004).

Notes: this species is characterised by immersed, branched lirellae with a whitish pruinose disc and split between disc and margin, 1-spored asci with eumuriform ascospores, and the presence of norstictic and stictic acids (Kalb et al. 2004).

Specimens examined: Fiji: Taveuni: near Naeangai village, altitude $1 \mathrm{~m}$, mangrove forest dominated by Heritiera litoralis, on mangrove, Lumbsch $19821 \mathrm{~h}$ (F, SUVA).

Dirinaria confluens (Fr.) D.D. Awasthi, Bibl. Lichenol. 2: 281 (1975)

Illustration: Fig. 4C.

Distribution: pantropical (Awasthi 1975, Elix 2009a).

Notes: this is a common, pantropical species, which is readily identified by the broad, adnate, longitudinally folded lobes, black lower surface, the absence of vegetative propagules, and the presence of divaricatic acid (Awasthi 1975).

Specimens examined: Fiji: Viti Levu: Nadi area, roadside between Lamawai and Nadi, altitude $2 \mathrm{~m}$, on mangrove, Lumbsch 19844a (F, SUVA).

Fissurina dumastii Fée, Essai Crypt. Exot. (Paris) 1: 59 (1825)

Illustration: Fig. 4D.

Distribution: pantropical (Staiger 2002).

Notes: this species has a poorly developed exciple, non- to faintly amyloid, 3-septate ascospores and lacks secondary metabolites (Staiger 2002).

Specimens examined: Fiji: Viti Levu: Monasavu, road to the Nabilabila intake, off the MonasavuWainisavulevu Fiji Electricity Authority access road, Agathis-Dacrydium dominated upland forest, on bark, Lumbsch 19825p (F, SUVA).

Fissurina dumastioides (Fink) Staiger, Bibl. Lichenol. 85: 161 (2002)

Illustration: Fig. 4E.

Distribution: pantropical (Staiger 2002).

Notes: this species differs from F. dumastii by containing stictic acid (Wirth \& Hale 1978).

Specimens examined: Fiji: Taveuni: access road to summit of Devo Peak, altitude $700 \mathrm{~m}$, montane relict forest at roadside, on bark, Lumbsch 19805g (F, SUVA).

Graphis caesiella Vain., Acta Soc. Fauna Fl. Fenn. 7(2): 122 (1890)

Illustration: Fig. 4F.

Distribution: pantropical (Archer 2009). 
Notes: this taxon is characterised by immersed to erumpent lirellae, entire, white pruinose labia, a laterally carbonised exciple, transversely septate ascospores, and the presence of norstictic acid (Lücking et al. 2008a).

Specimens examined: Fiji: Taveuni: Coconut Research Station, altitude $24 \mathrm{~m}$, coconut plantation, on Cocos nucifera, Lumbsch 19809 l-2 (F, SUVA).

Graphis duplicata Ach., Syn. Meth. Lich.: 81 (1814)

Illustration: Fig. 5A.

Distribution: pantropical (Lücking et al. 2008a).

Notes: this species lacks secondary metabolites and has a clear hymenium, prominent, striate lirellae lacking a thalline cover and transversely septate ascospores (Lücking et al. 2008a).

Specimens examined: Fiji: Taveuni: access road to summit of Devo Peak, altitude $700 \mathrm{~m}$, montane relict forest at roadside, on bark, Lumbsch 19804 s (F, SUVA).

Graphis intricata Fée, Essai Crypt. Exot., Suppl. (Paris): 42 (1837)

Illustration: Fig. 5B.

Distribution: pantropical (Archer 2009).

Notes: this species has narrow, richly branched lirellae, a entirely carbonised exciple, small ascospores, and contains the norstictic acid chemosyndrome (Archer 2009).

Specimens examined: Fiji: Viti Levu: Nadi area, roadside between Lamawai and Nadi, altitude $2 \mathrm{~m}$, on mangrove, Lumbsch 19844 (F, SUVA).

Graphis lineola Ach., Lich. Univ.: 264 (1810)

Illustration: Fig. 5C.

Distribution: pantropical (Archer 2009).

Notes: this species lacks secondary metabolites and is further characterised by having short, simple lirellae, a laterally carbonised exciple and an inspersed hymenium (Archer 2009).

Specimens examined: Fiji: Viti Levu: Nadi area, roadside between Korovuto and Nadi, altitude 2 m mangrove, on mangrove, Lumbsch 19841e, 19841h (F, SUVA).

Gyalectidium filicinum Müll.Arg., Flora, Jena 64: 101 (1881)

Illustration: Fig. 5D.

Distribution: pantropical (Lücking 2008).

Notes: this taxon is characterised by a verrucose, corticate thallus, yellowish green discs, and laminal to submarginal hyphophores with two lateral projections (Lücking 2008). Specimens examined: Fiji: Viti Levu: Monasavu, road to the Nabilabila intake, off the MonasavuWainisavulevu Fiji Electricity Authority access road, altitude 1200 m, cloud forest, on leaves, Lumbsch 19835e (F, SUVA).

Gyalectidium imperfectum Vezda, Nova Hedwigia 58: 131 (1994)

Illustration: Fig. 5E.

Distribution: pantropical (Lücking 2008). 

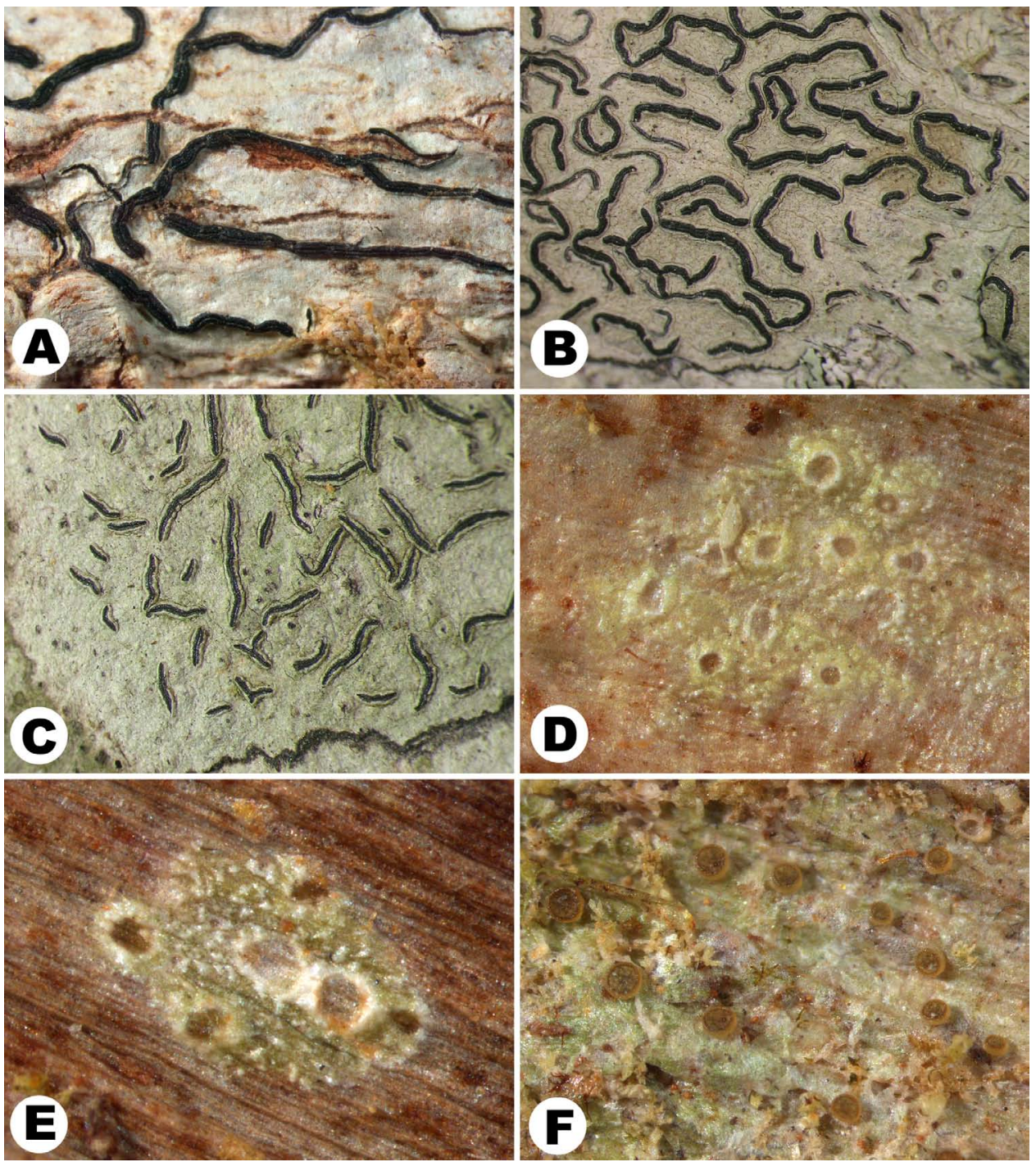

Fig. 5. A,. Graphis duplicata. B, Graphis intricata. C, Graphis lineola. D, Gyalectidium filicinum. E, Gyalectidium imperfectum. F, Gyalideopsis intermedia. 
Notes: this taxon is characterised by a verrucose, corticate thallus, yellowish green discs, and marginal hyphophores forming adnate, lunular, dark spots (Lücking 2008).

Specimens examined: Fiji: Viti Levu: Monasavu, road to the Nabilabila intake, off the MonasavuWainisavulevu Fiji Electricity Authority access road, altitude 1200 m, cloud forest, on leaves, Lumbsch 19835a (F, SUVA).

Gyalideopsis intermedia Lücking, Bibl. Lichenol. 65: 69 (1997)

Illustration: Fig. 5F.

Distribution: previously known from the Neotropics (Lücking 2008), reported here for the Paleotropics for the first time.

Notes: this species has a verrucose thallus, yellow apothecia, and 1-spored asci with eumuriform ascospores (Lücking 2008).

Specimens examined: Fiji: Viti Levu: Monasavu, road to the Nabilabila intake, off the MonasavuWainisavulevu Fiji Electricity Authority access road, altitude 1200 m, cloud forest, on leaves, Lumbsch $19835 i$ (F, SUVA).

Heterodermia incana (Stirt.) D.D.Awasthi, Geophytology 3: 114 (1973)

Illustration: Fig. 6A-B.

Distribution: Indo-Pacific (Kurokawa 1962).

Notes: this species lacks cilia on the thallus surface and at the apothecial margins, is esorediate, has a white lower surface, ecorticate, a I+ amyloid excipulum but I- medulla, and contains atranorin and zeorin.

Specimens examined: Fiji: Taveuni: access road to summit of Devo Peak, altitude $700 \mathrm{~m}$, montane relict forest at roadside, on bark, Lumbsch 19804w (F, SUVA).

Hypotrachyna imbricatula (Zahlbr.) Hale, Smithson. Contr. Bot. 25: 41 (1975)

Distribution: pantropical (Elix 1994a, Hale 1975).

Notes: this species is characterised by the cylindrical isidia, densely dichotomously branched rhizines, and the presence of barbatic acid (Elix 1994a).

Specimens examined: Fiji: Viti Levu: Monasavu, Guesthouse close to the dam, altitude 900 m, on lemon tree at parking lot of guesthouse, Lumbsch 19831d (MAF, SUVA), 19831e (MAF, SUVA); Nadarivatu Nature Reserve, secondary mountain forest at road to Koro'o, Lumbsch $19853 b$ (MAF, SUVA).

Lecanora helva Stizenb., Ber. Thätigk. St Gall. Naturwiss. Ges.: 218 (1890)

Illustration: Fig. 6C.

Distribution: pantropical (Guderley 1999, Lumbsch 1994).

Notes: this species belongs to a group of closely related tropical species with small, orange-brown apothecia, a granulose epihymenium, large crystals in the amphithecium, and small ascospores. This group also includes L. achroa Nyl. and $L$. leprosa Fée. Lecanora helva is mainly distinguished from these species in containing the 2'-O-methylperlatolic acid chemosyndrome (Lumbsch \& Elix 1993).

Specimens examined: Fiji: Taveuni: Coconut Research Station, altitude $24 \mathrm{~m}$, coconut plantation, on Cocos nucifera, Lumbsch 19809d, 19809n (F, SUVA); near Wiwi village, altitude 1 m, degraded mangrove, on mangrove, Lumbsch 19817a (F, SUVA); near Naeangai village, altitude $1 \mathrm{~m}$, mangrove-like coastal forest dominated by Heritiera litoralis, on fallen tree, Lumbsch $19824 b$ 
(F, SUVA). Viti Levu: Nadi area, mangrove at roadside between Samisoni and Nadi, altitude 2 m, on mangrove, Lumbsch 19843d, 19843o, 19844m (F, SUVA); Nadi area, close to Navisabasaba village, on road to Naduga from Nadi, altitude 2 m, on mangrove, Lumbsch 19845k (F, SUVA).

Lecanora leproplaca Zahlbr., in Magnusson \& Zahlbruckner, Ark. Bot. 31A(6): 64 (1944)

Illustration: Fig. 6D.

Distribution: pantropical (Lumbsch 2004).

Notes: this species is similar to L. tropica, but differs in having a sorediate thallus (Lumbsch 1994).

Specimens examined: Fiji: Taveuni: Bouma Falls, altitude $10 \mathrm{~m}$, relict forest, on bark, Lumbsch $19815 r$ (F, SUVA). Viti Levu: Nadi area, mangrove at roadside between Samisoni and Nadi, altitude 2 m, on mangrove, Lumbsch 19843c, 19843 m (F, SUVA); Nadi area, mangrove at roadside between Lamawai and Nadi, altitude 2 m, on mangrove, Lumbsch 19844h (F, SUVA).

Lecanora leprosa Fée, Essai Crypt. Exot. (Paris) 1: 118 (1825)

Illustration: Fig. 6E.

Distribution: pantropical (Lumbsch 2004).

Notes: this species is similar to L. helva, but can be distinguished by the presence of gangaleoidin and related substances (Lumbsch \& Elix 1993).

Specimens examined: Fiji: Viti Levu: Nadi area, roadside between Korovuto and Nadi, altitude 2 m, on mangrove, Lumbsch $19841 b$ (F, SUVA).

Lecanora subimmersa (Fée) Vain., Etud. Lich. Bres. 1: 98 (1890)

Illustration: Fig. 6F.

Distribution: pantropical (Lumbsch et al. 1994).

Notes: this Lecanora species is readily distinguished by having small, immersed apothecia (Lumbsch et al. 1994).

Specimens examined: Fiji: Taveuni: near Naeangai village, altitude $1 \mathrm{~m}$, mangrove-like coastal forest dominated by Heritiera litoralis, on siliceous rocks, Lumbsch 19820 (F, SUVA).

Lecanora tropica Zahlbr., Cat. Lich. Univers. 5: 589 (1928)

Illustration: Fig. 7A.

Distribution: pantropical (Lumbsch 1994).

Notes: this common, tropical species has red-brown apothecial discs, an egranulose epihymenium, large crystals in the amphithecium, and contains the chodatin chemosyndrome (Lumbsch 2004).

Specimens examined: Fiji: Viti Levu: Nadi area, roadside between Samisoni and Nadi, altitude $2 \mathrm{~m}$, on mangrove, Lumbsch 19843b, 19843 j (F, SUVA).

Lepraria lobificans Nyl., Flora 56: 196 (1873)

Illustration: Fig. 7B.

Distribution: cosmopolitan (Elix 2009b).

Notes: this common, cosmopolitan species has a whitish-grey, slightly lobate thallus and contains atranorin and the stictic acid chemosyndrome (Elix 2009b). 
Specimens examined: Viti Levu: Monasavu, road to the Nabilabila intake, off the MonasavuWainisavulevu Fiji Electricity Authority access road, cloud forest, altitude 1200 m, on siliceous rocks, Lumbsch 19840 a, $b$ (F, SUVA).

Leucodecton albidulum (Nyl.) Mangold, in Mangold et al., Fl. Australia 57: 654 (2009) Illustration: Fig. 7C.

Distribution: Australasian, previously known from eastern Australia and New Caledonia (Mangold et al. 2009).

Notes: it is characterised by a thick, ecorticate thallus, narrow, brown, transversely septate ascospores, and the presence of stictic acid (Mangold et al. 2009).

Specimens examined: Fiji: Viti Levu: Nadarivatu Nature Reserve, secondary mountain forest at road to Koro'o, altitude $750 \mathrm{~m}$, secondary mountain forest dominated by Agathis and Podocarpus, on bark, Lumbsch 19849w (F, SUVA).

Leucodecton occultum (Eschw.) Frisch, Bibl. Lichenol. 92: 157 (2006)

Illustration: Fig. 7D.

Distribution: pantropical (Mangold et al. 2009).

Notes: this species can be identified by the presence of an ecorticate thallus, more or less immersed, lepadinoid ascomata with a double margin, small, brown ascospores, and the presence of the norstictic acid chemosyndrome (Mangold et al. 2009).

Specimens examined: Fiji: Viti Levu: Nadi area, roadside between Korovuto and Nadi, altitude 2 m, mangrove, on Ficus, Lumbsch 19842a (F, SUVA).

Leucodecton phaeosporum (Nyl.) Rivas Plata \& Lücking, Lichenologist 42: 167 (2010) Illustration: Fig. 7E.

Distribution: pantropical (Mangold et al. 2009).

Notes: this species has a thick, bulging thallus and columnar crystal clusters similar to Leptotrema wightii (Taylor) Müll. Arg, which differs in having larger ascomata, in lacking stictic acid, and in containing small red anthroquinone crystals (Mangold et al. 2009). The two species are phylogenetically unrelated (Rivas Plata 2011).

Specimens examined: Fiji: Viti Levu: Nadarivatu Nature Reserve, road to Koro'o, altitude 750 m, secondary mountain forest dominated by Agathis and Podocarpus, on bark, Lumbsch 19854c (F, SUVA).

Megalospora sulphurata Meyen, in Meyen \& Flotow, Nova Acta Acad. Caes. Leop.-Carol. Nat. Cur. 19(suppl.): 228 (1843)

Illustration: Fig. 7F.

Distribution: pantropical (Sipman 1983).

Notes: Megalospora sulphurata is distinguished in having large 2-celled ascospores and an orange-brown epihymenium (Sipman 1983). The current circumscription of the species is very broad and probably includes distinct lineages (Untari 2006). One distinctive morphotype which occurs in Fiji has been treated elsewhere and represents a new species, Megalospora austropacifica (Lumbsch et al. 2011).

Specimens examined: Fiji: Taveuni:, access road to summit of Devo Peak, altitude $850 \mathrm{~m}$, relict cloud forest, on bark, Lumbsch 19801c (F, SUVA). Viti Levu: Nadarivatu Nature Reserve, road to Koro'o, altitude 900 m, roadside tree, on bark, Lumbsch 19847c (F, SUVA); Nadarivatu Nature 

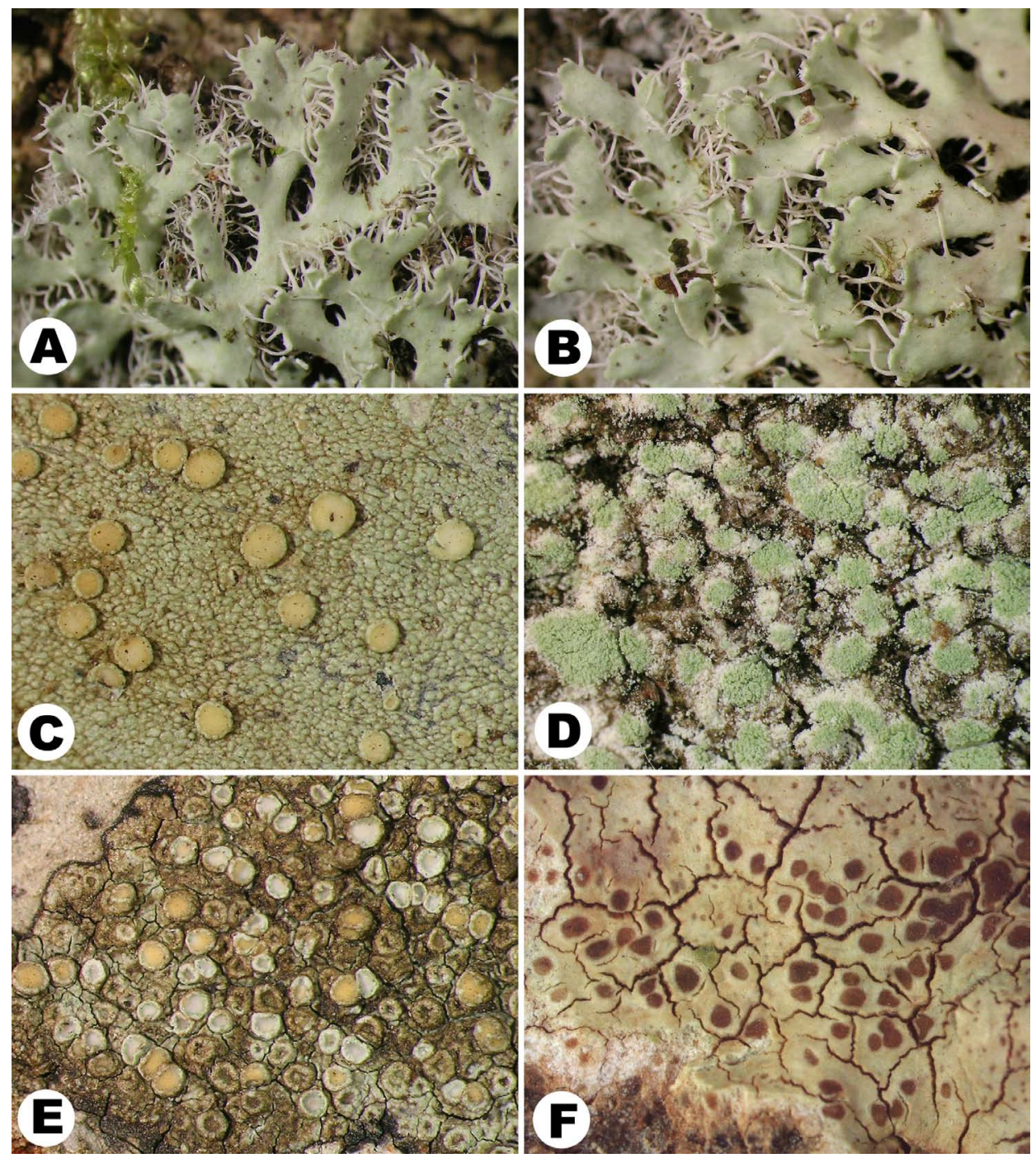

Fig. 6. A, B, Heterodermia incana. C, Lecanora helva. D, Lecanora leproplaca. E, Lecanora leprosa. F, Lecanora subimmersa. 

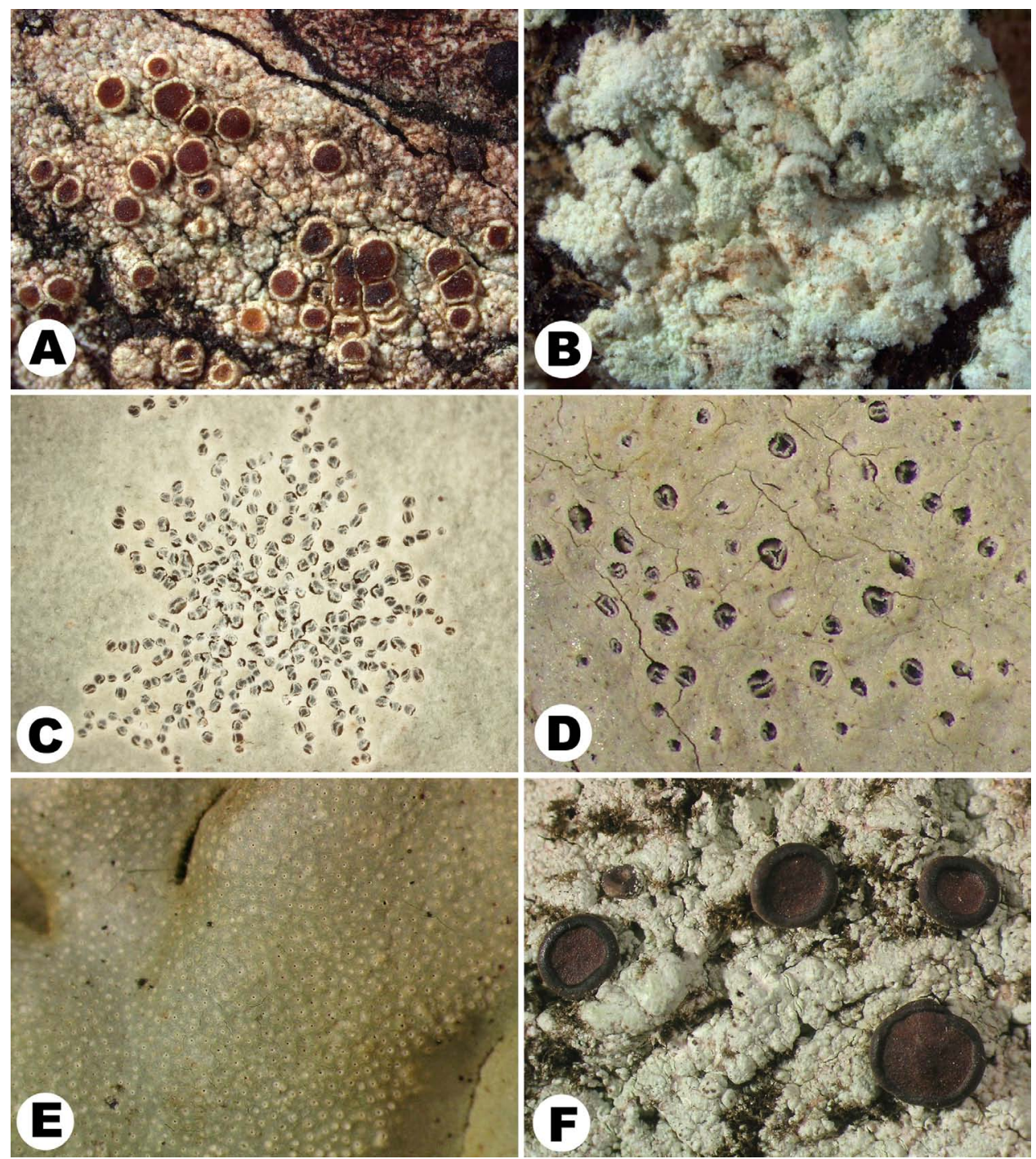

Fig. 7. A, Lecanora tropica. B, Lepraria lobificans. C, Leucodecton albidulum. D, Leucodecton occultum. E, Leucodecton phaeosporum. F, Megalospora sulphurata. 
Reserve, road to Koro'o, altitude $750 \mathrm{~m}$, secondary mountain forest dominated by Agathis and Podocarpus, on bark, Lumbsch 19850e (F, SUVA).

Melanotopelia rugosa (Kantvilas \& Vězda) Mangold \& Lumbsch, Lichenologist 40: 44 (2008)

Illustration: Fig. 8A.

Distribution: previously known from southern Argentina, Australia, southern Chile, Falkland Islands, and Auckland and Campbell Islands (Lumbsch et al. 2010, Mangold et al. 2009).

Notes: this taxon is characterised by urceolate, dark ascomata, a carbonised proper exciple, hyaline, muriform ascospores, and the presence of stictic acid (Lumbsch et al. 2010, Mangold et al. 2009, Mangold et al. 2008).

Specimens examined: Fiji: Viti Levu: Monasavu, road to the Nabilabila intake, off the MonasavuWainisavulevu Fiji Electricity Authority access road, altitude 1200 m, cloud forest, on mosses over bark, Lumbsch 19838a (F, SUVA).

Pannaria tavaresii P.M.Jørg., Oper .Bbot. 45: 68 (1978)

Illustration: Fig. 8B-D.

Distribution: pantropical, extending into mild, temperate areas (Jørgensen \& Galloway 1992).

Notes: this species is characterised by its coralloid, digitiform isidia (Jørgensen \& Galloway 1992).

Specimens examined: Fiji: Taveuni: Access road to summit of Devo Peak, altitude $850 \mathrm{~m}$, Relict cloud forest, over mosses on twigs, Lumbsch 19803c (F, SUVA).

Parmotrema abessinicum (Nyl. ex Kremp.) Hale, Phytologia 28: 334 (1974)

Distribution: pantropical (Divakar \& Upreti 2005).

Notes: the species is distinguished by ciliate lobe margins, perforate apothecia, simple rhizines in the thallus centre and in containing atranorin, norlobaridone, loxodin and protolichesterinic acid (Divakar \& Upreti 2005).

Specimens examined: Fiji: Taveuni:, access road to summit of Devo Peak, altitude $700 \mathrm{~m}$, montane relict forest at roadside, on bark, Lumbsch 19805a (F, SUVA).

Parmotrema hababianum (Gyeln.) Hale, Phytologia 28: 336 (1974)

Distribution: pantropical (Divakar \& Upreti 2005).

Notes: this taxon is characterised by short marginal cilia, sorediate margins, a lower surface with a white or mottled marginal zone, simple rhizines in the thallus centre and in containing atranorin, norlobaridone and protolichesterinic acid (Divakar \& Upreti 2005).

Specimens examined: Fiji: Viti Levu: Nadi area, roadside between Lamawai and Nadi, altitude $2 \mathrm{~m}$, on mangrove, Lumbsch 19844e (F, SUVA).

Peltigera sumatrana Gyeln., Rev. Bryol. Lich. 5: 72 (1932)

Illustration: Fig. 8E.

Distribution: south-east Asia (Serusiaux et al. 2009). 

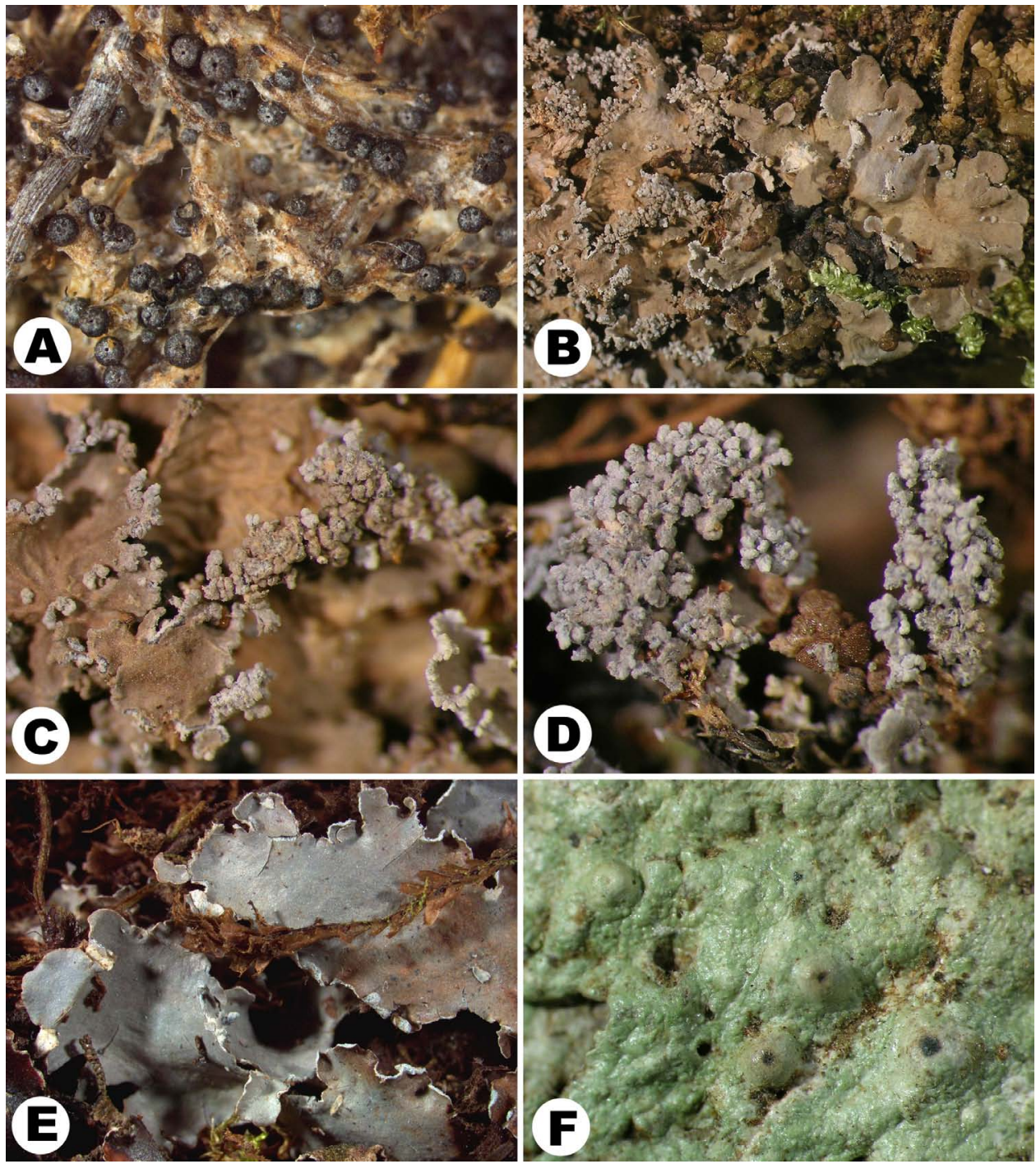

Fig. 8. A, Melanotopelia rugosa. B-D, Pannaria tavaresii. E, Peltigera sumatrana. F, Porina brisbanensis. 
Notes: this species is characterised by relatively large thalli, a smooth upper surface, and a jet black lower surface with elliptical and whitish interstices, the absence of veins, and densely branched rhizines.

Specimens examined: Fiji: Taveuni:, access road to summit of Devo Peak, open vegetation at summit, on soil, Lumbsch 19807 \& T. Pócs (F, SUVA). Fiji: Viti Levu: Monasavu, road to the Nabilabila intake, off the Monasavu-Wainisavulevu Fiji Electricity Authority access road, altitude $1200 \mathrm{~m}$, cloud forest, on tree base, Lumbsch 19833a, on mosses over bark, Lumbsch $19838 c$ (F, SUVA).

Porina brisbanensis Müll.Arg., Nuovo Giorn. Bot. Ital. 23: 402 (1891)

Illustration: Fig. 8F.

Distribution: pantropical.

Notes: this species is usually considered a synonym of Porina internigrans (Nyl.) Müll. Arg. because of the similar size and septation of the ascospores. However, it differs in the indistinct prothallus and the often conspicuously cracked thallus and particularly in the fine cracks radiating from the ostiolar area.

Specimens examined: Fiji: Viti Levu:Monasavu, road to the Nabilabila intake, off the MonasavuWainisavulevu Fiji Electricity Authority access road, altitude 950 m, Agathis-Dacrydium dominated upland forest, on fallen tree, Lumbsch 19826h (F, SUVA).

Pyrenula kurzii Ajay Singh \& Upreti, Geophytology 17: 81 (1987)

Illustration: Fig. 9A.

Distribution: palaeotropical.

Notes: this species is characterised by exposed, jet-black perithecia, an inspersed hymenium, and the mid-sized ascospores $($ c. $40 \times 15 \mu \mathrm{m})$ with the end cells somewhat pointed and not separated from the terminal wall by endospore.

Specimens examined: Fiji: Taveuni:, access road to summit of Devo Peak, altitude 1190 m, open vegetation at summit, on bark, Lumbsch 19800 c (F, SUVA).

Pyxine australiensis Kalb, Herzogia 10: 61 (1994)

Illustration: Fig. 9B.

Distribution: previously known from Australia and South America (Elix 2009a).

Notes: this taxon is characterised by the absence of isidia or soredia, a yellow medulla, apothecia with a white, internal stipe, and the presence of lichexanthone (Elix 2009a, Kalb 1994).

Specimens examined: Fiji: Viti Levu: Nadi area, roadside between Lamawai and Nadi, altitude 2 m, on mangrove, Lumbsch 19844d (F, SUVA).

Pyxine consocians Vain., Philipp. J. Sci., C, Bot. 8: 109 (1913)

Illustration: Fig. 9C.

Distribution: Indo-Pacific (Rogers 1986).

Notes: this taxon has polysidiangia that may become sorediate, contains atranorin in the cortex and the norstictic acid chemosyndrome in the white medulla (Kalb 1994, Rogers 1986).

Specimens examined: Fiji: Viti Levu: Nadi area, close to Navisabasaba village, on road to Naduga from Nadi, altitude 2 m, on mangrove, Lumbsch 19845a, 19845b (F, SUVA). 
Pyxine copelandii Vain., Philipp. J. Sci., C, Bot. 8: 110 (1913)

Illustration: Fig. 9D.

Distribution: previously known from tropical south-eastern Asia, Australia and New Guinea (Elix 2009a).

Notes: Pyxine copelandii has a white medulla, laminal, orbicular soralia, a colourless stipe and contains the norstictic acid chemosyndrome (Elix 2009a).

Specimens examined: Fiji: Taveuni: Bouma Falls, altitude $10 \mathrm{~m}$, relict forest, on bark, Lumbsch $19815 g$ (F, SUVA).

Pyxine farinosa Kashiw., Bull. Natl. Sci. Mus., Tokyo, B 3: 67 (1977)

Illustration: Fig. 9E.

Distribution: Indo-Pacific (Elix 2009a, Kashiwadani 1977).

Notes: this species is characterised by a yellow to yellow-orange medulla, laminal, orbicular soralia, a colourless stipe, and the presence of atranorin and triterpenes (Elix 2009a, Kashiwadani 1977).

Specimens examined: Fiji: Taveuni: Coconut Research Station, altitude $24 \mathrm{~m}$, coconut plantation, on Cocos nucifera, Lumbsch 19809e, j, o (F, SUVA).

Ramalina celastri (Spreng.) Krog \& Swinscow, Norw. J. Bot. 23: 159 (1976)

Illustration: Fig. 9F.

Distribution: pansubtropical (Stevens 1987).

Notes: this widely distributed Ramalina species is readily distinguished by the solid medulla, esorediate, flat thalli with numerous marginal and laminal apothecia, and the absence of medullary substances (Stevens 1987).

Specimens examined: Fiji: Taveuni: near Wiwi village, altitude $1 \mathrm{~m}$, degraded mangrove thicket, on mangrove, Lumbsch 19817 (F, SUVA).

Relicina abstrusa (Vain.) Hale, Phytologia 28: 484 (1974)

Distribution: pantropical (Elix 1994b).

Notes: this species is distinguished by the dark lower surface of the thallus, cylindrical isidia, and the presence of the norstictic acid chemosyndrome (Elix 1994b).

Specimens examined: Fiji: Viti Levu: Nadarivatu Nature Reserve, secondary mountain forest at road to Koro'o, altitude $750 \mathrm{~m}$, secondary mountain forest dominated by Agathis and Podocarpus, on bark, Lumbsch 19854 (F, SUVA).

Strigula maculata (Cooke \& Massee) R.Sant., Symb. bot. upsal. 12(1): 186 (1952)

Illustration: Fig. 10A.

Distribution: pantropical (Lücking 2008).

Notes: this species is recognised by the dark green thallus which features a thin black marginal line. The dark grees colour of the thallus causes the leaves to appear darkspotted from a distance, hence the epithet.

Specimens examined: Fiji: Viti Levu: Monasavu, road to the Nabilabila intake, off the MonasavuWainisavulevu Fiji Electricity Authority access road, altitude 1200 m, cloud forest, on leaves, Lumbsch $19835 g$ (F, SUVA). 

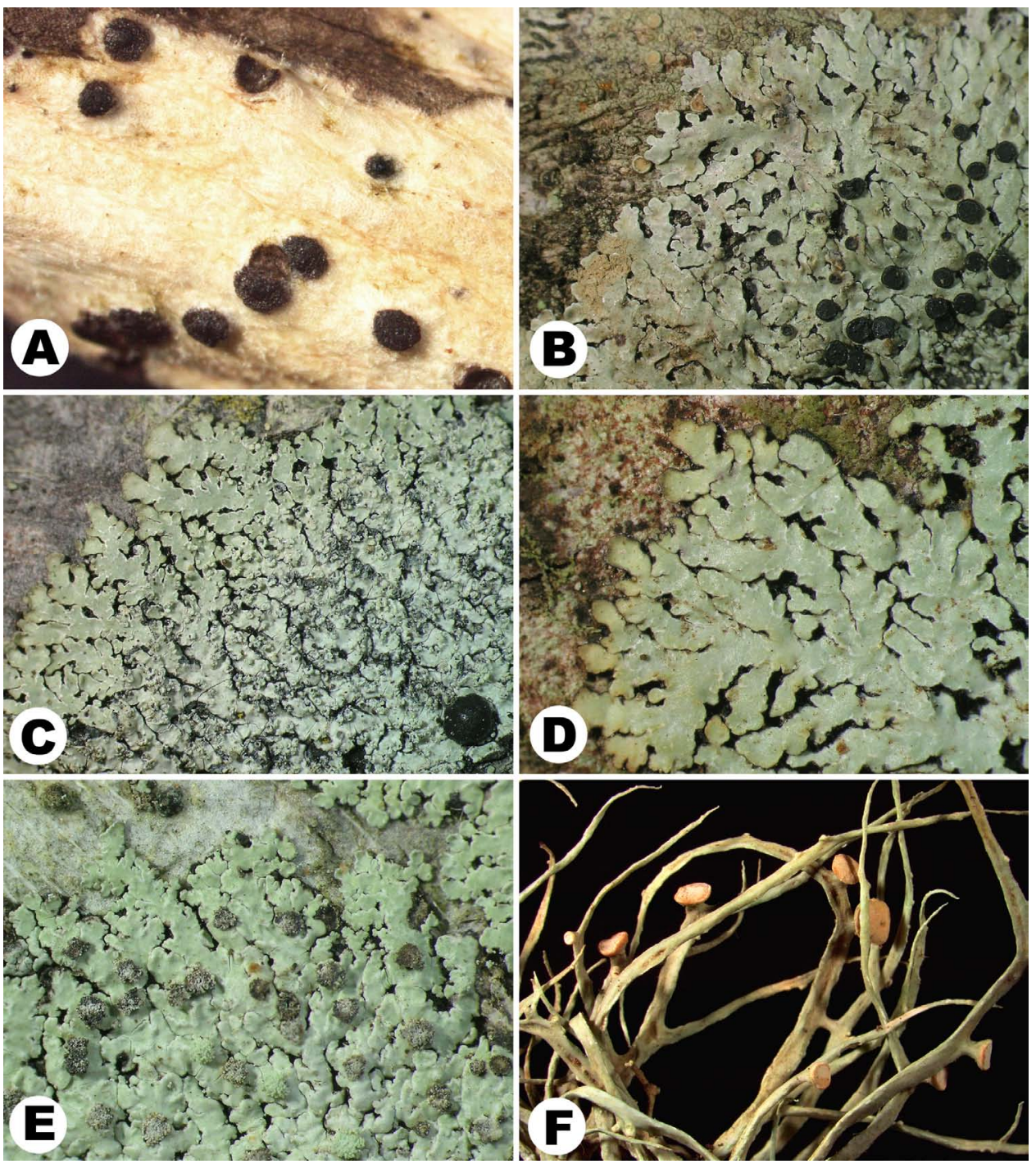

Fig. 9. A, Pyrenula kurzii. B, Pyxine australiensis. C, Pyxine consocians. D, Pyxine copelandii. E, Pyxine farinosa. F, Ramalina celastri. 
Strigula subtilissima (Fée) Müll.Arg., Flora 66: 346 (1883)

Illustration: Fig. 10B.

Distribution: pantropical (Lücking 2008).

Notes: this species is recognised by the olive-brown, finely lobate thallus which features a thin black marginal line. It is similar to the preceding species but differs in having more distinct lobes and the olive rather than dark green colour.

Specimens examined: Fiji: Viti Levu: Monasavu, road to the Nabilabila intake, off the MonasavuWainisavulevu Fiji Electricity Authority access road, altitude 1200 m, cloud forest, on leaves, Lumbsch $19835 b$ (F, SUVA).

Thalloloma janeirense Staiger, Bibl. Lichenol. 85: 440 (2002)

Illustration: Fig. 10C.

Distribution: previously known from South America (Staiger 2002).

Notes: this species is characterised by having brown apothecial discs, 4-8-spored asci, and short (up to $30 \mu \mathrm{m}$ long), muriform ascospores (Staiger 2002).

Specimens examined: Fiji: Taveuni: Bouma Falls, altitude $10 \mathrm{~m}$, relict forest, on bark, Lumbsch $19815 u$ (F, SUVA).

Thelotrema circumscriptum C.Knight, Trans. New Zealand Inst. 15: 349 (1883)

Illustration: Fig. 10D, E.

Distribution: hitherto known from cool-temperate to subtropical rainforests in southern Argentina, Lord Howe Island, Auckland Islands, and New Zealand (Lumbsch et al. 2010).

Notes: this species has lepadinoid ascomata, transversely septate, hyaline, non-amyloid ascospores, and contains salazinic acid (Lumbsch et al. 2010).

Specimens examined: Fiji: Viti Levu: Monasavu, road to the Nabilabila intake, off the MonasavuWainisavulevu Fiji Electricity Authority access Road, altitude 950 m, Agathis-Dacrydium dominated upland forest, on bark, Lumbsch 19825a (F, SUVA).

Thelotrema defossum (Müll.Arg.) Mangold, Aust. Syst. Bot. 21: 221 (2008)

Illustration: Fig. 10F.

Distribution: previously recorded from Australia, Lord Howe Island and Timor (Mangold et al. 2009).

Notes: Thelotrema defossum is characterised by immersed apothecia and small, faintly amyloid, halonate ascospores with thin walls, and the absence of secondary metabolites (Lumbsch et al. 2008).

Specimens examined: Fiji: Viti Levu: Nadarivatu Nature Reserve, road to Koro'o, altitude 750 m, secondary mountain forest dominated by Agathis and Podocarpus, on bark, Lumbsch $19849 y$ (F, SUVA).

Thelotrema diplotrema Nyl., Annls Sci. Nat., Bot., sér. 4, 11: 258 (1859)

Illustration: Fig. 11A.

Distribution: palaeotropical (Mangold et al. 2009).

Notes: this species has immersed to slightly emergent apothecia, large, transversely septate, thick-walled, amyloid ascospores, and lacks secondary metabolites (Mangold et al. 2009). 

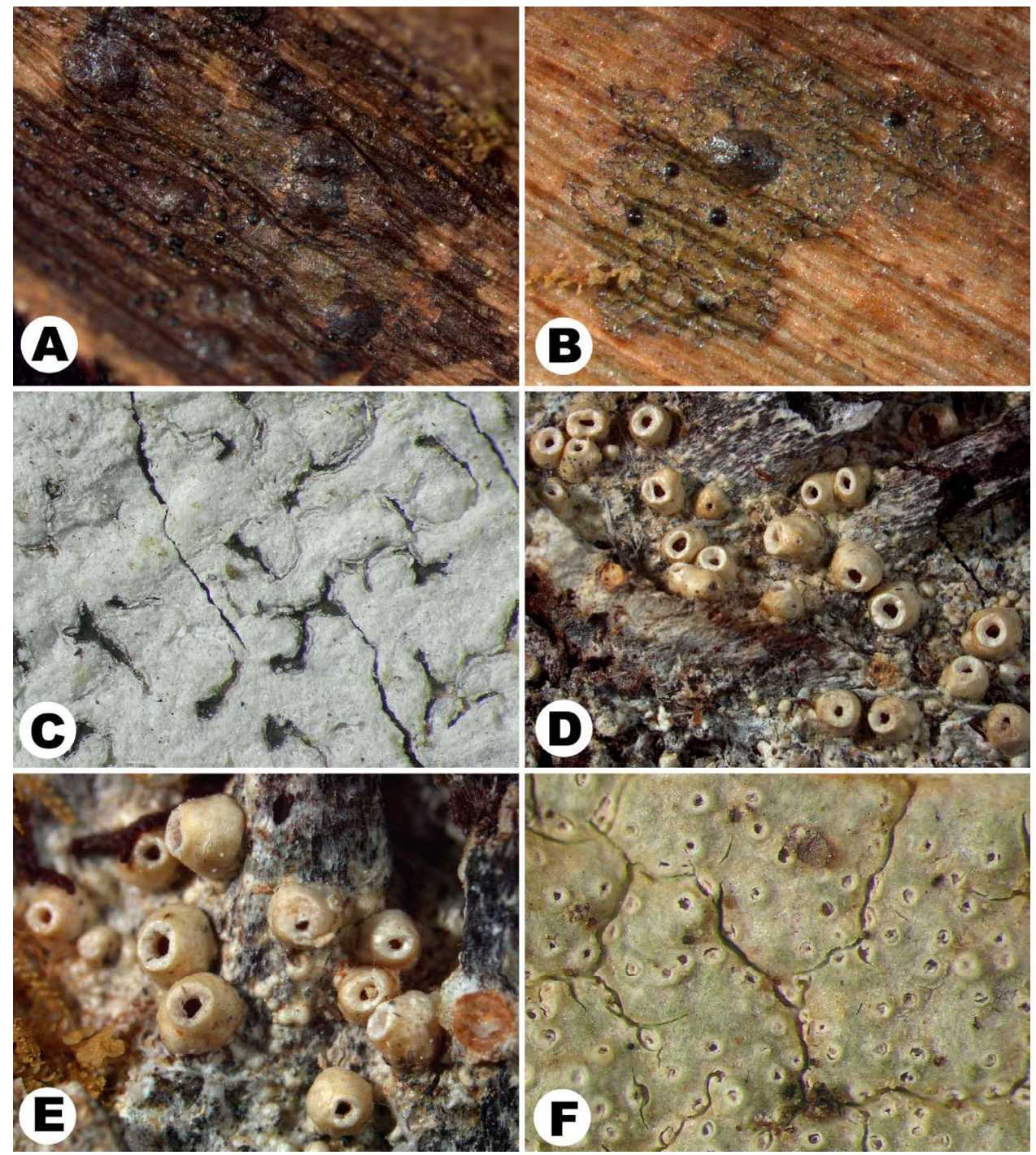

Fig. 10. A, Strigula maculata. B, Strigula subtilissima. C, Thalloloma janeirense. D, E, Thelotrema circumscriptum. F, Thelotrema defossum. 

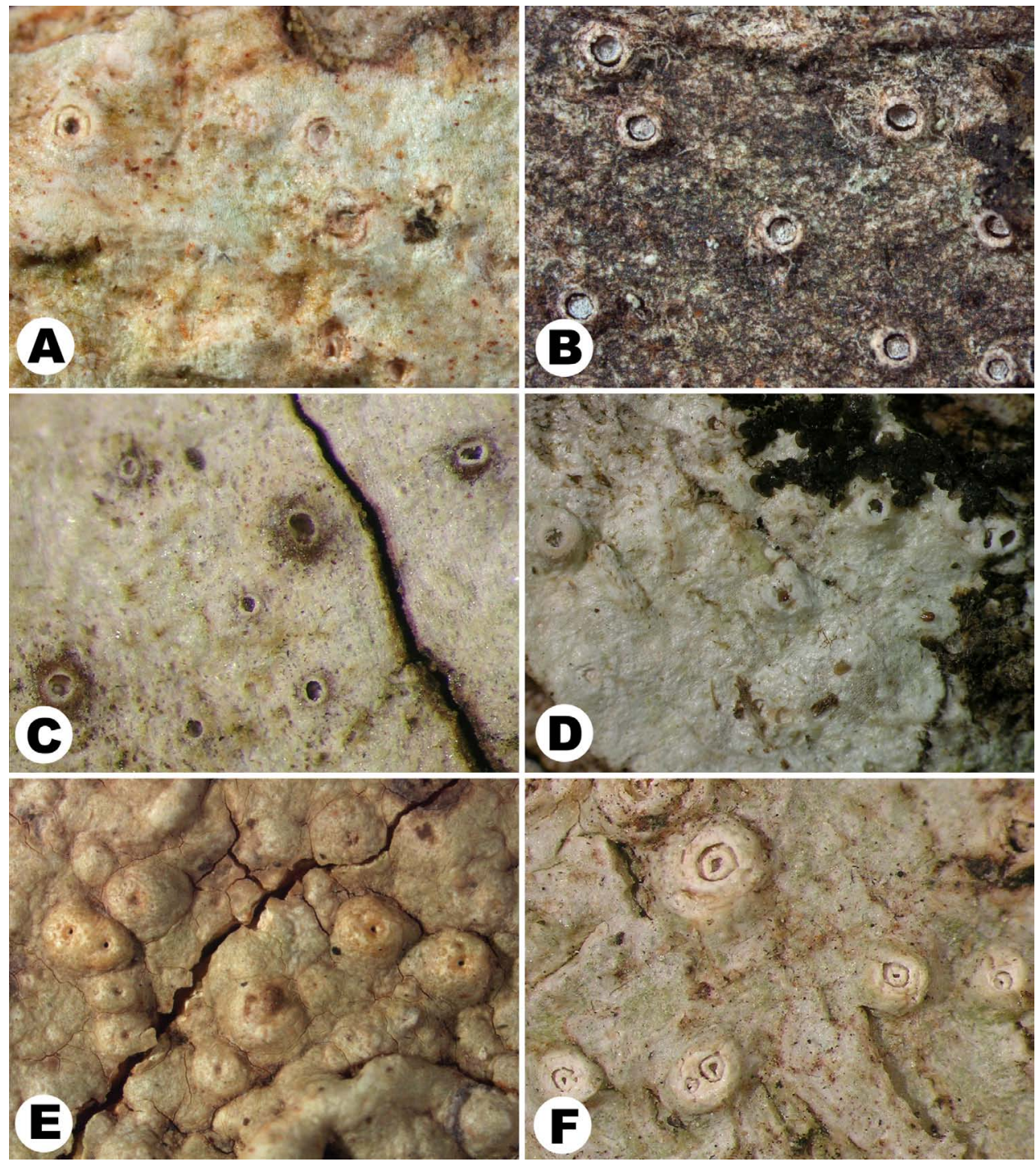

Fig. 11.A, Thelotrema diplotrema. B, Thelotrema lacteum. C, Thelotrema lepadodes. D, Thelotrema pachysporum. E, Thelotrema porinaceum. F, Thelotrema porinoides. 
Specimens examined: Fiji: Taveuni:, access road to summit of Devo Peak, altitude $850 \mathrm{~m}$, relict cloud forest, on bark, Lumbsch 19801b (F, SUVA).

Thelotrema lacteum Kremp., in Nylander, Flora, Jena 47: 269 (1864)

Illustration: Fig. 11B.

Distribution: pantropical (Mangold et al. 2009).

Notes: this species somewhat resembles a Chapsa in ascoma morphology because of the widely exposed disc, but has an entire thalline margin; it features brown, transversely septate ascospores and lacks secondary metabolites (Mangold et al. 2009).

Specimens examined: Fiji: Viti Levu: Nadi area, roadside between Samisoni and Nadi, altitude 2 m, on mangrove, Lumbsch 19843a (F, SUVA).

Thelotrema lepadodes Tuck., Proc. Amer. Acad. Arts Sci. 5: 405 (1862)

Illustration: Fig. 11C.

Distribution: pantropical (Mangold et al. 2009).

Notes: Thelotrema lepadodes is morphologically similar to the common and widespread T. lepadinum (Ach.) Ach., but is readily distinguished by having a non-corticate, more or less whitish thallus and brownish, non- to faintly amyloid ascospores.

Specimens examined: Fiji: Taveuni: Bouma Falls, altitude $10 \mathrm{~m}$, relict forest, on bark, Lumbsch $19815 m$ (F, SUVA).

Thelotrema pachysporum Nyl., Bull. Soc.Llinn. Normandie 2: 72 (1868)

Illustration: Fig. 11D.

Distribution: pantropical (Mangold et al. 2009).

Notes: as the name of this species suggests, it has large, thick-walled ascospores. These are transversely septate, brown and weakly amyloid. The asci are 4-8-spored asci and the taxon lacks secondary metabolites (Mangold et al. 2009). In other respects this species is morphologically similar to the preceding one.

Specimens examined: Fiji: Taveuni:, access road to summit of Devo Peak, altitude $700 \mathrm{~m}$, montane relict forest at roadside, on bark, Lumbsch 19804a (F, SUVA).

Thelotrema porinaceum Müll.Arg., Nuovo Giorn. Bot. Ital. 23: 130 (1891)

Illustration: Fig. 11E.

Distribution: palaeotropical (Mangold et al. 2009).

Notes: this taxon is characterised by a thick thallus, immersed fruiting bodies, large, muriform ascospores, and the presence of the norstictic acid chemosyndrome (Mangold et al. 2007). Norstictic acid is rare among Thelotrema species. Species containing norstictic acid include T. eungellaense Mangold, Elix \& Lumbsch, T. subweberi Sipman, and T. weberi Hale. The two latter species are readily distinguished by their sessile, urceolate ascomata, while T. eungellaense has 4-spored asci and smaller ascospores.

Specimens examined: Fiji: Viti Levu: Nadarivatu Nature Reserve, road to Koro'o, altitude 750 m, secondary mountain forest dominated by Agathis and Podocarpus, on bark, Lumbsch $19849 \mathrm{f}$ (F, SUVA). 
Thelotrema porinoides (Mont. \& Bosh), Enum. Plant. Ins. Java Sumatra: 484 (1855)

Illustration: Fig. 11F.

Distribution: pantropical (Mangold et al. 2009). This species is the most common thelotremoid Graphidaceae in Fiji.

Notes: the species is readily distinguished by the emergent apothecia with a free proper exciple, transversely septate, hyaline, thick-walled, and strongly amloid ascospores, and the presence of stictic acid (Mangold et al. 2009).

Specimens examined: Fiji: Taveuni:: access road to summit of Devo Peak, altitude $1190 \mathrm{~m}$, open vegetation at summit, on bark, Lumbsch $19800 \mathrm{~b}$ (F, SUVA); altitude $850 \mathrm{~m}$, relict cloud forest, on twigs, Lumbsch 19802b (F, SUVA); altitude $700 \mathrm{~m}$, montane relict forest at roadside, on bark, Lumbsch 19804l, 19804n, q, 19805d (F, SUVA). Viti Levu: Monasavu, road to the Nabilabila intake, off the Monasavu-Wainisavulevu Fiji Electricity Authority access road, altitude 1200 m, cloud forest, on bark, Lumbsch 19834 (F, SUVA); Nadarivatu Nature Reserve, road to Koro'o, altitude $750 \mathrm{~m}$, secondary mountain forest dominated by Agathis and Podocarpus, on twigs, Lumbsch 19851 (F, SUVA); Monasavu, road to the Nabilabila intake, off the Monasavu-Wainisavulevu Fiji Electricity Authority access road, altitude 950 m, Agathis-Dacrydium dominated upland forest, on bark, Lumbsch 19825n, $19826 \mathrm{~g}$ (F, SUVA); altitude $1100 \mathrm{~m}$, cloud forest, on bark, Lumbsch 19829c (F, SUVA); Nadi area, roadside between Samisoni and Nadi, altitude $2 \mathrm{~m}$, on mangrove, Lumbsch 19843k (F, SUVA); Nadarivatu Nature Reserve, Telecom Towers, altitude $970 \mathrm{~m}$, isolated trees at logged summit, on bark, Lumbsch 19846b (F, SUVA); altitude $750 \mathrm{~m}$, secondary mountain forest dominated by Agathis and Podocarpus, on bark, Lumbsch 19850d, 19854 e (F, SUVA).

\section{Acknowledgments}

This study was supported by the National Geographic Committee for Research and Exploration, Grant No. 8247-07. HTL, MVK and AN wish to thank Allan Fife (CHR), Tamas Pòcs (Felsőtárkány), Elizabeth Brown (NSW), John E. Braggins (Auckland), Matt Renner (NSW), Marika Tuiwawa and Jone Navuso (both SUVA), for their company and help during a joint expedition to Fiji. Kevin Havener (Chicago) is thanked for help with the formatting of the text.

\section{References}

Aptroot A. \& Sipman H. (1991) New lichens and lichen records from New Guinea. Willdenowia 20: 221-256.

Archer A.W. (1992) Cladoniaceae. Flora of Australia 54: 107-152.

Archer A.W. (2004) Additions to the lichen flora of Fiji and Vanuatu based on Graphidaceae in the F.R.M. Wilson collection at the National Herbarium of New South Wales. Telopea 10: $771-776$.

Archer A.W. (2009) Graphidaceae. Flora of Australia 57: 84-194.

Arvidsson L. (1982) A monograph of the lichen genus Coccocarpia. Opera Botanica 67: 1-96.

Arvidsson L. (1992) Coccocarpiaceae. Flora of Australia 54: 153-159.

Awasthi D.D. (1975) A monograph of the lichen genus Dirinaria. Bibliotheca Lichenologica 2: $1-108$.

Chaves J.L., Lucking R., Sipman H.J.M., Umaña L. \& Navarro E. (2004) A first assessment of the ticolichen biodiversity inventory in Costa Rica: The genus Dictyonema (Polyporales : Atheliaceae). Bryologist 107: 242-249. 
Divakar P.K. \& Upreti D.K. (2005) Parmelioid lichen in India (A revisionary study). Bishen Singh Mahendra Pal Singh, Dehra Dun, India.

Dodge C.W. (1953) Some lichens from tropical Africa. Annals of the Missouri Botanical Garden 40: 271-401.

Egea J.M. \& Torrente P. (1995) Melampilidium metabolum belongs in Bactrospora. Mycotaxon 53: $57-61$.

Elix J.A. (1994a) Hypotrachyna. Flora of Australia 55: 49-59.

Elix J.A. (1994b) Relicina. Flora of Australia 55: 168-182.

Elix J.A. \& McCarthy P.M. (1998) Catalogue of the lichens of the smaller Pacific islands. Bibliotheca Lichenologica 70: 1-361.

Elix J.A. (2001) Additional lichen records from Oceania 7. Parmeliaceae from Fiji. Australasian Lichenology 48: 34-37.

Elix J.A. \& McCarthy P.M. (2008) Checklist of Pacific Island Lichens. http://www.anbg.gov.au/ abrs/lichenlist/PACIFIC_introduction.html.

Elix J.A. (2009a) Physciaceae. Flora of Australia 57: 494-533.

Elix J.A. (2009b) Stereocaulaceae. Flora of Australia 57: 60-73.

Galloway D.J. (1980) Notes on the lichen genus Baeomyces in New Zealand. Botaniska Notiser 133: 77-83.

Galloway D.J. (2007) Flora of New Zealand Lichens. Revised Second Edition Including LichenForming and Lichenicolous Fungi. Volumes 1 and 2. Manaaki Whenua Press, Lincoln, New Zealand.

Gierl C. \& Kalb K. (1993) Die Flechtengattung Dibaeis. Eine Übersicht über die rosafrüchtigen Arten von Baeomyces sens. lat. nebst Anmerkungen zu Phyllobaeis gen. nov. Herzogia 9: 593645.

Guderley R. (1999) Die Lecanora subfusca-Gruppe in Süd- und Mittelamerika. Journal of the Hattori Botanical Laboratory 87: 131-257.

Hafellner J. (1997) A world monograph of Brigantiaea (lichenized Ascomycotina, Lecanorales). Symbolae Botanicae Upsalienses 32 (1): 35-74.

Hale M.E. (1975) A revision of lichen genus Hypotrachyna (Parmeliaceae) in tropical America. Smithsonian Contributions to Botany 25: 1-73.

Harada H. (2001) Taxonomic notes on pyrenocarpous lichens in Japan (4). Anisomeridium ubianum (Vain.) R.C. Harris (Monoblastiaceae). Hikobia 13: 411-414.

Harris R.C. (1995) More Florida Lichens. Including the 10c Tour of the Pyrenolichens. Publ. by the Author, Bronx, N.Y.

Heads M. (2006) Seed plants of Fiji: an ecological analysis. Biological Journal of the Linnean Society 89: 407-431.

Johnston J. (2001) Baeomycetaceae. Flora of Australia 58A: 14-16.

Jorgensen P.M. \& Galloway D.J. (1992) Pannariaceae. Flora of Australia 54: 246-293.

Kalb K. (1994) Pyxine species from Australia. Herzogia 10: 61-69.

Kalb K. (2001) New or otherwise interesting lichens. I. Bibliotheca Lichenologica 78: 141-167.

Kalb K. (2004) Pyxine species from Australia. Herzogia 10: 61-69.

Kalb K., Staiger B. \& Elix J.A. (2004) A monograph of the lichen genus Diorygma - a first attempt. Symbolae Botanicae Upsalienses 34(1): 133-181.

Kashiwadani H. (1977) The genus Pyxine (lichens) in Papua New Guinea. Bulletin of the National Science Museum [Tokyo] 3B: 63-70.

Keppel G. (2005) Botanical studies within the PABITRA wet-zone transect, Fiji: Viti Levu: Fiji. Pacific Science 59: 165-174.

Krempelhuber A. von (1873) Beitrag zur Kenntniss der Lichenen-Flora der Südsee-Inseln. Journal des Museum Godeffroy, Geographische, ethnographische und naturwissenschaftliche Mittheilungen 1: 93-110.

Kurokawa S. (1962) A monograph of the genus Anaptychia. Beihefte zur Nova Hedwigia 6: 1-115. Lücking R. (2008) Foliicolous lichenized fungi. Flora Neotropica 103: 1-867. 
Lücking R., Chaves J.L., Sipman H.J.M., Umaña L. \& Aptroot A. (2008a) A first assessment of the Ticolichen Biodiversity Inventory in Costa Rica: the genus Graphis, with notes in the genus Hemithecium (Ascomycota: Ostropales: Graphidaceae). Fieldiana (Botany) 46: 1-131.

Lücking R. (2008b) Foliicolous lichenized fungi. Published for the Organization for Flora Neotropica by The New York Botanical Garden Press.

Lücking R.,Lumbsch H.T. \& von Konrat M. (2010) Graphis collinsiae (Ascomycota: Graphidaceae), a new lichen species from the Fiji Islands. Bryologist 113: 356-359.

Lumbsch H.T. \& Elix J.A. (1993) Notes on the circumscription of the lichens Lecanora leprosa and L. sulphurescens (Lecanoraceae, lichenised Ascomycotina). Tropical Bryology 7: 71-75.

Lumbsch H.T. (1994) Die Lecanora subfusca-Gruppe in Australasien. Journal of the Hattori Botanical Laboratory 77: 1-175.

Lumbsch H.T., Feige G.B. \& Elix J.A. (1994) Chemical variation in two species of the Lecanora subfusca group (Lecanoraceae, lichenized Ascomycotina). Plant Systematics and Evolution 191: 227-236.

Lumbsch H.T. (2004) Lecanoraceae. In: Flora of Australia. Volume 56A, Lichens 4 (McCarthy P.M. and Mallett K. eds): 11-12. ABRS/CSIRO Australia, Melbourne.

Lumbsch H.T., Mangold A., Martin M.P. \& Elix J.A. (2008) Species recognition and phylogeny of Thelotrema species in Australia (Ostropales, Ascomycota). Australian Systematic Botany 21: 217-227.

Lumbsch H.T., Papong K. \& Naikatini A. (2009) A new terricolous species of Gyalidea (Gomphillaceae, Ascomycota) from Fiji. Nova Hedwigia 88: 111-116.

Lumbsch H.T., Divakar P.K., Messuti M.I., Mangold A. \& Lücking R. (2010) A survey of thelotremoid lichens (Ascomycota: Ostropales) in subantarctic regions excluding Tasmania. Lichenologist 42: 203-224.

Lumbsch H.T., Ahti T., Altermann S., Amo G., Aptroot A., Arup U., Barcenas Peña A., Bawingan P.A., Benatti M.N., Betancourt L., Björk C.R., Boonpragob K., Brand M., Bungartz F., Caceres M., Candan M., Chaves J.L., Clerc P., Common R., Coppins B.J., Crespo A., Dal Forno M., Divakar P.K., Duya M.V., Elix J.A., Elvebakk A., Fankhauser J., Farkas E., Ferraro L.I., Fischer E., Galloway D.J., Gaya E., Giralt M., Goward T., Grube M., Hafellner J., Hernández J., Herrera-Campos M.A., Kalb K., Kärnefelt I., Kantvilas G., Killmann D., Kirika P., Knudsen K., Komposch H., Kondratyuk S., Lawrey J.D., Mangold A., Marcelli M.P., Mccune B., Michlig A., Miranda Gonzalez R., Moncada B., Naikatini A., Nelsen M.P., Øvstedal D.O., Palice Z., Papong K., Parnmen S., Pérez-Ortega S., Printzen C., Rico V.J., Rivas Plata E., Robayo J., Rosabal D., Ruprecht U., Salazar Allen N., Sancho L., Santos De Jesus L., Santos Vieira T., Schultz M., Seaward M.R.D., Sérusiaux E., Schmitt I., Sipman H.J.M., Sohrabi M., Søchting U., Søgaard M.Z., Sparrius L., Spielmann A.A., Spribille T., Sutjaritturakan J., Thammathaworn A., Thell A., Thor G., Thüs H., Timdal E., Truong C., Türk R., Umaña Tenorio L., Upreti D.K., Van Den Boom P., Vivas Rebuelta M., Wedin M., Will-Wolf S., Wirth V., Wirtz N., Yahr R., Yeshitela K., Ziemmeck F. \& Lücking R. (2011) One hundred new species of lichenized fungi: a signature of undiscovered global diversity. Phytotaxa 18: 1-127.

Mangold A., Elix J.A. \& Lumbsch H.T. (2007) The norstictic acid containing Thelotrema species in Australia. Bibliotheca Lichenologica 95: 459-470.

Mangold A., Martin M.P., Kalb K., Lucking R. \& Lumbsch H.T. (2008) Molecular data show that Topeliopsis (Ascomycota, Thelotremataceae) is polyphyletic. Lichenologist 40: 39-46.

Mangold A., Elix J.A. \& Lumbsch H.T. (2009) Thelotremataceae. Flora of Australia 57: 195-420.

Marbach B. (2000) Corticole und lignicole Arten der Flechtengattung Buellia sensu lato in den Subtropen und Tropen. Bibliotheca Lichenologica, 74, J. Cramer, Berlin, Stuttgart.

McCarthy P.M. \& Elix J.A. (2000) Additional lichen records from Oceania 4. Some pyrenolichens in Fiji. Australasian Lichenology 46: 40-42.

Messuti M.I. (1996) Notes on the lichen genus Coccotrema in southern South America. New Zealand Journal of Botany 34: 57-64.

Messuti M.I. \& Vobis G. (2002) Flora Criptogámica de Tierra del Fuego. Vol. 13, Fasc. 13. Lichenes Pertusariales: Coccotremataceae, Megasporaceae, Pertusariaceae. Consejo Nacional de Investigaciones Cientificas y Técnicas, Buenos Aires. 
Molho D.M., Bodo B., Culberson W.L. \& Culberson C.F. (1981) A chemically distinctive new Ramalina from Fiji. Bryologist 84: 396-398.

Rivas Plata E. (2011) Historical biogeography, ecology and systematics of the family Graphidaceae (Lichenized Ascomycota: Ostropales). Ph. D. Thesis, University of Illinois at Chicago, Chicago.

Rivas Plata E., Lücking R., Aptroot A., Sipman H.J.M., Umana L., Chaves J.L. \& Lizano D. (2006) A first assessment of the Ticolichen biodiversity inventory in Costa Rica: the genus Coenogonium (Ostropales: Coenogoniaceae). Fungal Diversity 23: 255-321.

Rogers R.W. (1986) The genus Pyxine (Physiaceae, lichenized Ascomycetes) in Australia. Australian Jounral of Botany 34: 131-154.

Santesson R. (1952) Foliicolous Lichens I. A revision of the taxonomy of the obligately foliicolous, lichenized fungi. Symbolae Botanicae Upsalienses 12: 1-590.

Serusiaux E., Goffinet B., Miadlikowska J. \& Vitikainen O. (2009) Taxonomy, phylogeny and biogeography of the lichen genus Peltigera in Papua New Guinea. Fungal Diversity 38: $185-224$.

Sipman H.J.M. (1983) A monograph of the lichen family Megalosporaceae. Bibliotheca Lichenologica 18: 1-241.

Staiger B. (2002) Die Flechtenfamilie Graphidaceae. Studien in Richtung einer natürlicheren Gliederung. Bibliotheca Lichenologica 85: 1-526.

Stevens G.N. (1987) The lichen genus Ramalina in Australia. Bulletin of the British Museum (Natural History), Botany Series 16: 107-223.

Streimann H. (1986) Catalogue of the Lichens of Papua New Guinea and Irian Jaya. Bibliotheca Lichenologica 22: 1-145.

Untari L.F. (2006) The lichen genus Megalospora in Java. Mycotaxon 97: 129-143.

von Konrat M, Naikatini A, Tuiwawa M, Söderström L, Fife A, Renner M, Brownsey P, Perrie L, Hagborg A, Pócs T, Lumbsch HT, Braggins J, Séneca A \& Brown E (2011) A brief history of the cryptogams of Fiji and prospects for the future. Telopea 13:361-374.

Wirth M. \& Hale M.E. Jr (1978) Morden-Smithsonian Expedition to Dominica: the lichens (Graphidaceae). Smithsonian Contributions to Botany 40: 1-64.

Zahlbruckner A. (1896) Lichenes Mooreani. Annalen des Kaiserlich-Königlichen naturhistorischen Hofmuseums zu Wien 11: 188-196.

Manuscript received 29 May 2010 and accepted 29 May 2011. 